\title{
INSTITUTIONAL MAPPING TOWARDS DEVELOPING A FRAMEWORK FOR SUSTAINABLE MARINE SPATIAL PLANNING
}

\author{
Muhammad Hafiz Mohd Yatimª, Abdullah Hisam Omar ${ }^{\mathrm{a}}$, Nazirah Mohamad Abdullah ${ }^{\mathrm{a}}$, Noorshahrizan Mohd Hashim ${ }^{\mathrm{b}}$ \\ a'Department of Geomatic and Real Estate, Universiti Teknologi Malaysia (UTM), Skudai, Johor, Malaysia - \\ hafizyatim3005@gmail.com, abdullahhisham@utm.my,my_nazirah@yahoo.com \\ bUniversiti Teknologi MARA Perlis (UiTM), Arau, Perlis, Malaysia - norshahrizan@perlis.uitm.edu.my
}

KEY WORDS: Marine Spatial Planning, Marine Government Institutions, Sustainability

\begin{abstract}
:
Within few years before, the urge to implement the marine spatial planning is due to increasing numbers of marine activities that will lead into uncertainties of rights, restrictions and responsibilities of the maritime nations. Marine authorities in this situation that deal with national rights and legislations are the government institutions that engage with marine spatial information. There are several elements to be considered when dealing with the marine spatial planning; which is institutional sustainability governance. Providing the importance of marine spatial planning towards sustainable marine spatial governance, the focus should highlight the role marine institutions towards sustainable marine plan. The iterative process of marine spatial planning among marine institutions is important as the spatial information governance is scattered from reflected rights, restrictions and responsibilities of marine government institutions. Malaysia is one of the maritime nations that conjures the initial step towards establishing the sustainable marine spatial planning. In order to have sustainable institutions in marine spatial planning process, it involves four main stages; planning phase, plan evaluation phase, implementation phase and post implementation phase. Current situation has witnessed the unclear direction and role of marine government institutions to manage the marine spatial information. This review paper is focusing on the institutional sustainability upon interaction of marine government institutions in the marine spatial planning process based on Institutional Analysis Framework. The outcome of the integration of institutional sustainability and marine spatial planning process will propose a framework of marine institutional sustainable plan.
\end{abstract}

\section{INTRODUCTION}

The need to highlight the importance to implement marine spatial planning among maritime nation has been virtue. Marine spatial planning is seen as a new tool to achieve sustainable marine spatial governance. Most importantly, the need to know who is eligible and how efficiently the spatial information is managed; is the most prominent among all. The current world trend of development regarding the maritime nations is expanding to the coastal area. Hence, the development includes activities such as fisheries, shipping and tourism can be seen as the triggered factors to effectively manage the coastal realm.

Over the last decade, the discussion on marine spatial governance has become phenomenon among scholars. Marine spatial governance is highlighted as the solution to sustainably manage the marine areas. Scholars such as (Strain et al., 2006; Rajabifard et al., 2005; Binns, 2004 and Binns et al., 2004) have highlighted that in order to implement a marine spatial governance, there are three issues that need to be clarified. The First issue is the legal issues that include the rules and regulations regarding the jurisdiction of managing the marine spatial information; the second issue is the technical issue. Technical issues are therefore include the software's and hardware's to collect the marine spatial data, process and distribute the data among other users. Finally, the third issue is the institutional/ stakeholder issue that needed the central agency to collect, process and disseminate the marine information up to the public reach.

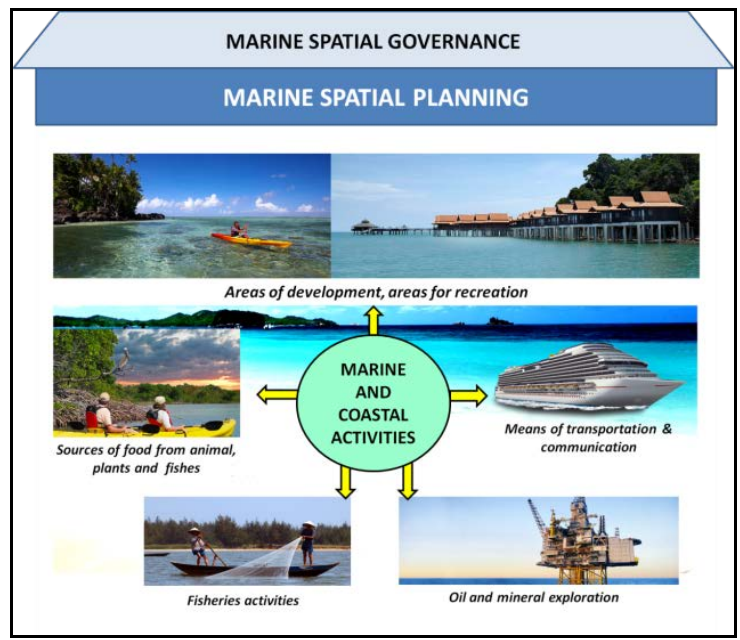

Figure 1. Marine and Coastal Activities that relates to Marine Spatial Planning and Marine Spatial Governance

Hence, the need to have a marine policy towards governing the spatial information has been highlighted by most of the nation. Since there is no policy and strategic plans on implementing the marine spatial planning, it caused to overlapping of jurisdiction among most of the institutions that involve with marine activities as stated in Figure 1. Therefore, the priority is focus on mapping out the marine institutions arrangement towards sustaining the marine spatial planning process. 
2.

\section{MARINE SPATIAL PLANNING PROCESS}

Marine spatial planning is the first important step into the governing marine spatial information. Marine spatial planning is the concept of coordination or integration of government functions between institutions and federal-state governance in relation to the preparation and adoption of marine spatial plans. It is an effective consultation with institutional and the society during plan preparation (Heffernan, 2015 and Jay et al., 2012).

As for this review the marine spatial planning is about introducing the framework of managing the spatial activities among marine institutions to achieve strategic sustainable development (Jay et al., 2016; Dunstan et al., 2016; Caldow et al., 2015; Olsen et al., 2014; Kelly et al., 2014; Frazão et al., 2014; Stelzenm et al., 2013; Jay et al., 2012 and Calado et al., 2010).

Even though the precise definition of marine spatial planning is never into certain agreement (Gopnik et al., 2012), it is clear that from the definitions, the marine spatial planning is aiming for the sustainable development of marine resources planning and governance, not just environmental protection; and the fact that marine spatial planning can be considered as the integrated tools (Chang and Lin, 2016; Carneiro, 2013; Agardy et al., 2011; and Backer, 2011) to resolve the conflicts among marine users (Calado and Bentz, 2013).

Majority of previous scholars have stressed that marine spatial planning is a process, not a single plan or outcome. Marine spatial planning is known as the cycles of process towards achieving a sustainable plan to govern the marine spatial information. The implementation of marine spatial planning involves certain stages towards strategic plans of marine spaces. Moreover, the iterative process of marine spatial planning introduced by (Calado et al., 2012) includes:-
i) Data collection;
ii) Stakeholder consultation;
iii) Participatory development of a plan; and
iv) Subsequent stages of implementation, enforcement, evaluation and revision.

However (Heffernan, 2015) had enhanced the process into nine (9) specific stages as shown in Figure 2.

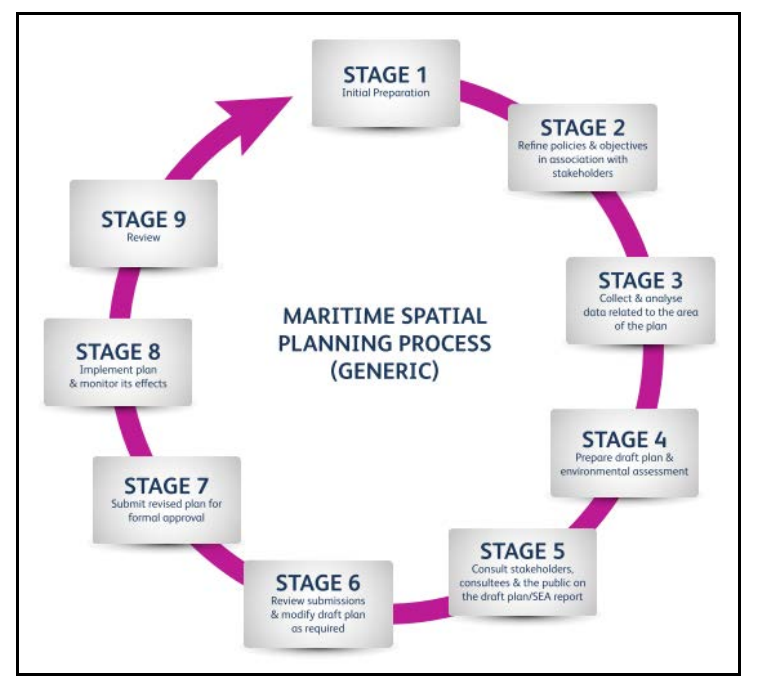

Figure 2. Marine Spatial Planning Process (Heffernan, 2015)
The involvement of institutions is important and includes at all stages (Havard et al., 2015; Veidemane and Nikodemus, 2014; Flannery and Cinneide, 2012; Ounanian, Delaney and Raakjær, 2012; Gopnik et al., 2012; Backer, 2011 and Gilliland and Laffoley, 2008).

Hence, in order to ensure the effectiveness of marine spatial planning implementation, the key principle is marine institutions participation. In order to achieve broad acceptance, ownership and support for implementation, it is equally important to involve all institutions, including coastal regions, at the earliest possible stage in the planning process. Furthermore, the institutions participation is also a source of knowledge that can significantly raise the quality of marine spatial planning (Heffernan, 2015).

\section{MARINE SPATIAL INSTITUTIONS}

With such overlapping responsibilities from various activities in marine and coastal area, it is important to address the future direction of the marine institutions. Marine institutions can be varied from government, non-government and academia that involve with governance of marine spatial information. When we are dealing with marine spatial planning process, it will involve the policy making on the implementation. Hence, the marine policy matters will focus on the involvement and responsibilities of marine government institutions. (Abdullah Hisham Omar et al., 2015) had introduced the list of marine government institutions in Malaysia as shown in Table 1.

From the nine stages of implementation of marine spatial planning, it can be grouped into four theme phases which are:-
i) Planning Phase
ii) Plan Evaluation Phase
iii) Implementation Phase
iv) Post implementation Phase

Moreover, the institutional plans should involve at every theme stages as shown in Figure 3.

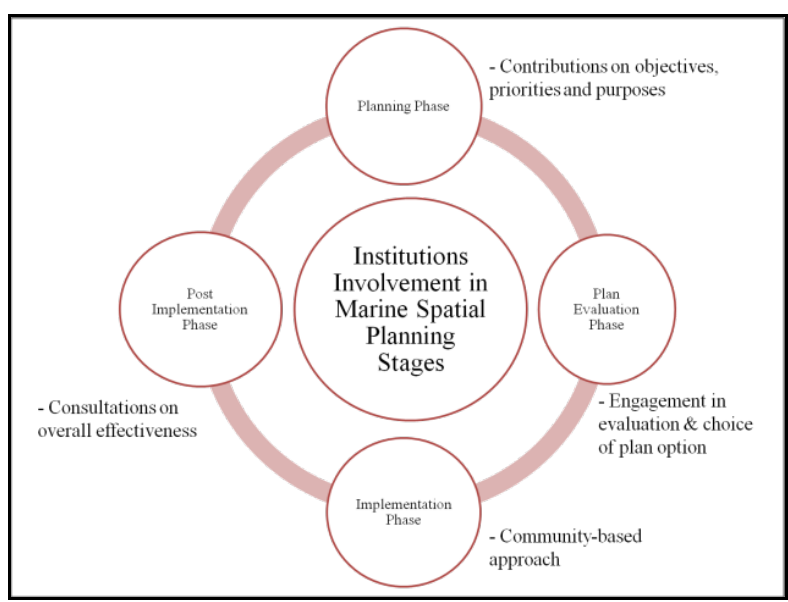

Figure 3. Institutions Involvement in Marine Spatial Planning Stages (Modified after Gopnik et al., 2012 and Pomeroy and Douvere, 2008) 
Table 1. List of Marine Related Institutional (Abdullah Hisham Omar et al., 2015)

\begin{tabular}{|c|c|c|c|}
\hline No & Category & Ministry & Institutions \\
\hline 1. & Port & \multirow{3}{*}{$\begin{array}{c}\text { Ministry of } \\
\text { Transport } \\
\\
\text { Prime } \\
\text { Minister's } \\
\text { Department } \\
\\
\text { Ministry of } \\
\text { International } \\
\text { Trade and } \\
\text { Industry }\end{array}$} & $\begin{array}{l}\text { - Department/Agencies } \\
\text { - Johor Port Autority } \\
\text { - Bintulu Port Autority } \\
\text { - Klang Port Authority } \\
\text { - Kuantan Port Autority } \\
\text { - Kemaman Port Autority - } \\
\text { Penang Port Comission } \\
\text { - Maritime Institute of } \\
\text { Malaysia (MIMA) }\end{array}$ \\
\hline 2. & Shipping & & $\begin{array}{l}\text { - Marine Department of } \\
\text { Malaysia } \\
\text { - Maritime Institute of } \\
\text { Malaysia }\end{array}$ \\
\hline 3. & Light house & & $\begin{array}{l}\text { - Marine Department of } \\
\text { Malaysia }\end{array}$ \\
\hline \multirow[t]{2}{*}{4.} & \multirow[t]{2}{*}{$\begin{array}{l}\text { Non-living } \\
\text { resources }\end{array}$} & $\begin{array}{l}\text { Ministry of } \\
\text { Science and } \\
\text { Technology }\end{array}$ & $\begin{array}{l}\text { - Department of Standard } \\
\text { Malaysia ( STANDARD } \\
\text { MALAYSIA) } \\
\text { - National Oceanographic } \\
\text { Directorate (NOD) } \\
\text { - Malaysia Remote Sensing } \\
\text { Agency (ARSM) } \\
\text { - Malaysia Meteorological } \\
\text { Department }\end{array}$ \\
\hline & & $\begin{array}{c}\text { Prime } \\
\text { Minister's } \\
\text { Department } \\
\text { Ministry of } \\
\text { Transport }\end{array}$ & $\begin{array}{l}\text { - Economic Planning Unit } \\
\text { (EPU) } \\
\text { - Maritime Institute of } \\
\text { Malaysia (MIMA) }\end{array}$ \\
\hline \multirow[b]{2}{*}{5.} & \multirow[b]{2}{*}{$\begin{array}{l}\text { Living resources/ } \\
\text { fisheries }\end{array}$} & $\begin{array}{c}\text { Ministry of } \\
\text { Agriculture } \\
\text { and Agro- } \\
\text { Based Industry }\end{array}$ & $\begin{array}{l}\text { - Department of Fisheries } \\
\text { - Fisheries Development } \\
\text { Authority of Malaysia } \\
\text { (LKIM) }\end{array}$ \\
\hline & & $\begin{array}{c}\text { Prime } \\
\text { Minister's } \\
\text { Department } \\
\text { Ministry of } \\
\text { Transport } \\
\end{array}$ & $\begin{array}{l}\text { - Maritime Institute of } \\
\text { Malaysia (MIMA) }\end{array}$ \\
\hline 6. & Natural resources & \multirow{2}{*}{$\begin{array}{c}\text { Ministry of } \\
\text { Natural } \\
\text { Resources and } \\
\text { Environment } \\
\text { Ministry of } \\
\text { Transport } \\
\text { Prime } \\
\text { Minister's } \\
\text { Department }\end{array}$} & $\begin{array}{l}\text { - National Hydraulic } \\
\text { Research Institute } \\
\text { Research Institute of } \\
\text { Malaysia (NAHRIM) } \\
\text { - Department of Survey and } \\
\text { Mapping Malaysia } \\
\text { (JUPEM) } \\
\text { - Department of Director } \\
\text { General of Lands and Mines } \\
\text { (JKPTG) } \\
\text { - Department of Irrigation } \\
\text { and Drainage (JPS) } \\
\text { - Minerals and Geoscience } \\
\text { Department (JMG) } \\
\text { - Maritime Institute of } \\
\text { Malaysia (MIMA) }\end{array}$ \\
\hline 7. & $\begin{array}{l}\text { Forestry/ } \\
\text { Wildlife }\end{array}$ & & $\begin{array}{l}\text { - Department of Marine } \\
\text { Park Malaysia } \\
\text { - Department of } \\
\text { Environment Forestry } \\
\text { - Department Peninsular } \\
\text { Malaysia Forest Research } \\
\text { Institute Malaysia } \\
\text { - Department of Wildlife } \\
\text { and National Park } \\
\text { - Department of Biosafety } \\
\text { Maritime Institute of } \\
\text { Malaysia }\end{array}$ \\
\hline
\end{tabular}

\section{THE NEEDS FOR THE INSTITUTIONAL PLAN IN MARINE SPATIAL PLANNING}

It is mentioned earlier that the urgency for most maritime nations to enact marine spatial planning into marine institutions is because of the increasing numbers of activities that revolve around marine spaces. Activities such as port, shipping, light house for shipping, living and non-living resources, natural resources, forestry, wildlife, jurisdiction, enforcement, tourism, heritage, telecommunication, dispute settlement as well as education (Putten et al., 2016; Abdullah Hisham Omar et al., 2015 \& Calado \& Bentz, 2013) are resulting the overlapping roles and responsibilities for marine government institutions to govern the situation.

Moreover, the overlapping roles and responsibilities in marine environment often create a 'silent' gap among the institutions. Most of the institutions tend to work separately in term of data collection, data processing and data sharing among others (Nazirah Mohamad Abdullah et al., 2014; Abdullah Hisham Omar et al., 2015; Ng'ang'a et al., 2004; Binns, 2004a and Binns et al., 2004b. This situation will lead into "silo" phenomenon which referring to the same data redundancies collected by multiple institutions with the same mean for spatial governance.

In spite of that, the difference of objectives among the institutions towards soaring the department achievements, sometimes it may lead towards misunderstanding of certain phenomena. As for certain institutions, the environmental issues might be addressed as management problems, as for others it might be a technical problems or social problems (Liu et al., 2012) , (Haley et al., 2011). Hence, without a proper guidelines on the roles and responsibilities to achieve the mutual understanding, the vision to systematic govern the marine spaces were never became reality.

Therefore, in Malaysian context, most of the situations mentioned above occur as neither marine spatial governance nor marine spatial planning is still at the infancy stages, the framework of institutional strategies is important to make the first step for the marine institutions.

\section{RESEARCH METHODOLOGY}

This paper explores survey method as the research strategy as mixed method strategy will be imposed. The combination of qualitative and quantitative method will try to fill the missing gap from different perspectives. Differs from previous scholars which case study has been chosen as the research strategy (González et al., 2015; Sosa and Zwarteveen, 2014; Wang et al., 2013; Perez et al., 2012; Richmond and Levine, 2012; Machain et al., 2012; Capistrano, 2007 and Kay et al., 2003), the mixed method survey as performed by (Baiju, 2013) is selected for this review. As for the research approach, questionnaire distribution and interviews will be conducted for data collection. The selection of the respondents will be on purposive sampling as the method is efficient to estimate ratio and systematic to seek out the rich information cases, broad learning opportunities and meets multiple interests and needs (Ryzin, 2016; Buttivant \& Knai, 2012; Liddle \& El-Kafafi, 2010 and Karmel \& Jain, 1987).

The mixed method implied for this paper will be validated using triangulation method as suggested by (Jarvis et al., 2015). Triangulation method is the most suitable method to validate combination of research methodologies to study the same phenomenon. Moreover, this method of validation is to obtain confirmation of final findings through finalization from different perspectives (Jack \& Raturi, 2006 and Mangan et al., 2004). The three pillar of triangulation will be based on the sustainable elements as explained in section 6 .

Meanwhile, the full transcribed data from the interview session will be analyzed using NVIVO software and as for the questionnaire data, the SPSS software will be used for analysis. 


\section{SUSTAINABILITY ELEMENTS IN THE ECOSYSTEM BASED MANAGEMENT}

There are wide and variety definitions of sustainability according to academia publications on the field of study especially in the ecosystem based management (EBM). The ecosystem based management is known as the interactions within environmental approach and human sustainable management to achieve mutual targets (Soma et al., 2015; Sandström et al., 2015 and Haley et al., 2011).

The variety of definitions to represent sustainability is because of the different requirement of certain knowledge scope (Roberts and Brink, 2010). Commonly, according to United Nation back in year 1987 defined sustainability as the development that meets present needs without compromising the ability of future generations to meet their own needs (Agostini et al., 2015; Burdon et al., 2015; Hernandez et al., 2012; Stocker and Kennedy, 2009; Marine Aquaculture Task Force, 2007 and IOC/UNESCO, IMO, FAO, 2011).

The sustainability is the most important element (Schlüter et al., 2013) especially to study the institutional legislative directions (Sozialwissenschaften, 2013) in the coastal and marine realm because it relates to provides a policy framework and baseline spatial data to guide the placement of marine developments (Chen and Tsai, 2015; Sala et al., 2015; Kelly et al., 2014 and Giardino et al., 2011).

Most scholars have agreed that sustainability is built by three main pillars; ecological, economic and social (Sala et al., 2015; Inglés et al., 2015; Röckmann et al., 2015; Heffernan, 2015; Taljaard and Niekerk, 2013; Portman, 2015; Gopnik et al., 2012; Madu and Kuei, 2012; Portman, 2011 and Stocker and Kennedy, 2009) as illustrated in Figure 4.

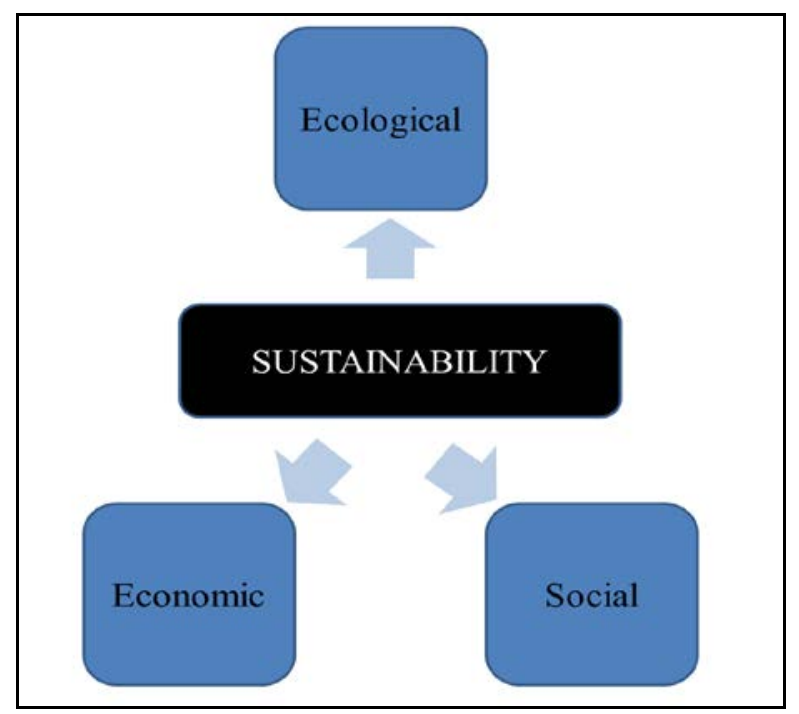

Figure 4. Elements of Sustainability

The element of economic represents the ability of current plan to achieve economic growth and achieving objectives for marine resources (Blackstock et al., 2015; Carter, 2014; Carneiro, 2013 and Calado et al., 2012).

The ecological element deals with the development related to managing marine resources, optimizing the potential of environmental resources and improved protection and enhancement of the marine environment (Chaffin et al., 2016; Carter, 2014; Carcamo et al., 2014; Carneiro, 2013; Calado et al., 2012; Capistrano, 2007 and Carvalho and Clarke, 1998). It also reduces the risk of damage to ecosystems sustainably.

Finally, the social element pictures the social development and participatory approach. Hence, the marine planning will assist in promoting the appreciation, understanding and a sense of ownership of the diversity of the marine environment (Carter, 2014; Carcamo et al., 2014; Carneiro, 2013; Calado et al., 2012 and Capistrano, 2007). The social pillar will improve the quality of life for coastal communities through stronger connection between coastal economies and environment development.

In order to obtain the sustainability framework of ecosystem based in marine spatial planning, the marine government institutional will be grouped specifically into the sustainability elements. The group of marine government institutions is based on the category in Table 1 .

\section{FRAMEWORK OF INSTITUTIONAL MAPPING IN SUSTAINABLE MARINE SPATIAL PLANNING}

Among all, to propose the framework of sustainable marine spatial plan among marine institutional, it leaves an important gap to be filled which is the understanding of sustainability and institutional directive plan. As mentioned earlier, the legislation direction is related to establishing the marine policies; the policymaker in Malaysia as parliament is the national legislature falls under the responsibilities of government institutions. Hence, the sample boundaries limit into Malaysia Government Marine Institutions which deals with marine spatial information. The selection of marine related government institutions according to the main sectors is shown in Figure 5.

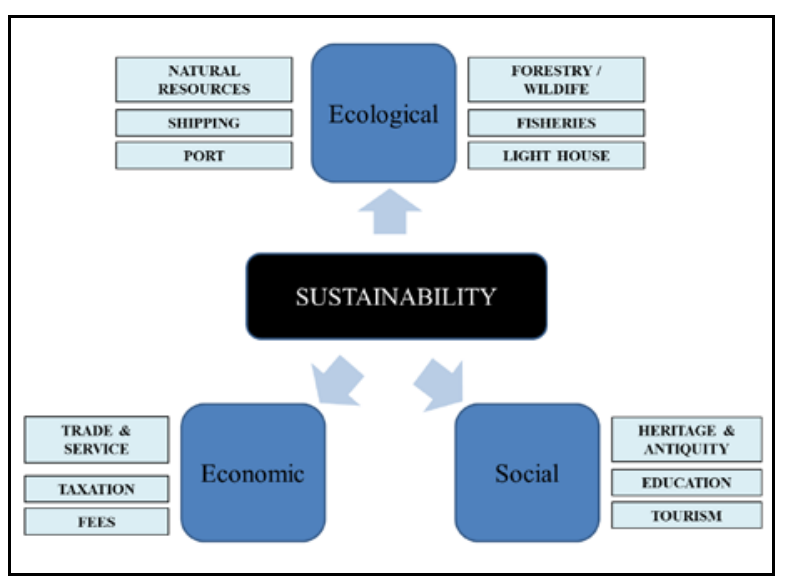

Figure 5. Institutional Sustainability according to Marine Government Sectors

Leading towards developing a framework of institutional strategic direction for sustainable marine spatial planning, it is best suggested to use the Institutional Analysis Framework. Furthermore, the implementation of Institutional Analysis as the method to study the legislative direction and relationship among marine institutions (Skurray, 2015; Zhang et al., 2014; Cárcamo et al., 2013; Liu et al., 2012 and Ostrom, 2005; 2010). 
The final output of the research is to develop and validate the framework of sustainable marine institutional directions. This framework generally helps to identify the elements and relationships among these elements that one needs to consider for institutional analysis. Moreover, the framework also provides a theoretical language to analyze the institutional arrangements (Ostrom, 2010).

(Ostrom, 2010) has introduced a framework of Institutional Analysis and Development (IAD) as shown in Figure 6. From the framework, there are three main elements to study the IAD which are physical/ material conditions, attributes of community and rules in use. These three elements will be tested to the action situations and actors. Finally, the outcomes are based on the pattern of interactions supported by the evaluative criteria.

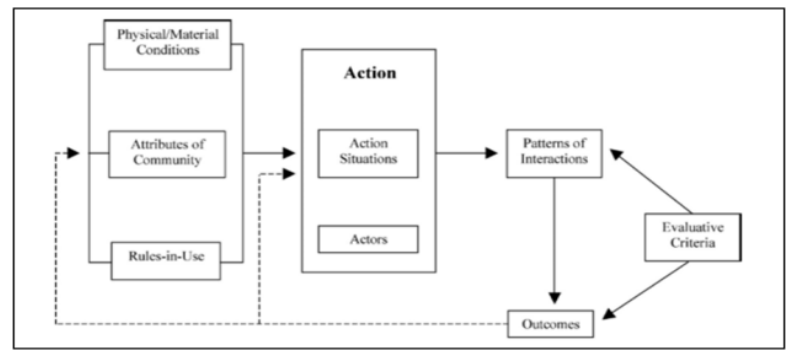

Figure 6. Framework for Institutional Analysis and Development (Ostrom, 2005; 2010).

Based on the Institutional Analysis Framework in Figure 6, the framework adapted in this research to strategically bind between institutional selection and sustainable marine spatial planning is Institutional Analysis Framework as illustrated in Figure 7.

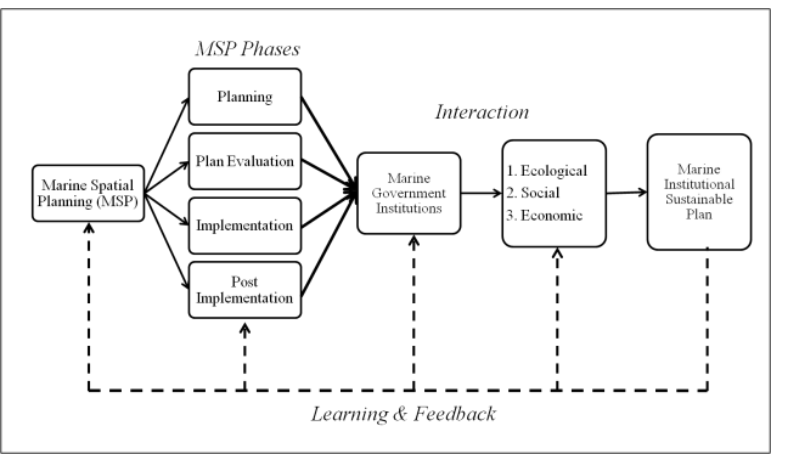

Figure 7. A Framework of Marine Government Institutional Sustainability

From the framework suggested in Figure 7 above, the result from interaction of institutional sustainability through marine spatial planning process will lead to marine institutional sustainable plan.

\section{CONCLUSION}

This review paper highlights the combination of marine institutional sustainability and marine spatial planning process in order to illustrate the framework of sustainable marine institutional plan. By introduction on the sustainability among marine institutions, this review proposes to explain on how the interaction of the marine government institutions in the marine spatial planning process can lead toward institutional sustainable plan. Sustainability in institutional perspective is referred to as the finding the sustainable plan that satisfied current as well as the future issues.

The expected outcome from the review are the institutional sustainable plans that will lead to strategic directive of marine government institutions. The sustainable concept will cover the three (3) main elements; social, economic and ecological. The sustainability from the marine institutions approach will cause the dynamic and maintained marine spatial planning. Hence, the framework from this review will become an answer to the efficient and strategic planning as well as the governance among marine government institutions.

Therefore, the sustainability is the symbolic of the strategic planning and governance that is reliable to the current and also future situation. Referring to the framework suggested in this review, it is hoped that sustainability in marine spatial planning among marine government institutions will be developed. However it is still recommended to fill a gap of adapting the element of institutional analysis to predict the institutional strategies and propose policies for future direction of marine institutions.

\section{REFERENCES}

Abdullah Hisham Omar, Nazirah Mohamad Abdullah, Shuib Rambat, Noor Anim Zanariah Yahaya, Rashiela Rahibulsadri, Asraf Abdullah, Rahim Yahya, Hasan Jamil, Chee Hua, T., Keat Lim, C., Omar, A. H., Abdullah, N. M. and Rambat, S., (2015), Sustainable Marine Space Managements : Malaysia Perspective.

Agardy, T., di Sciara, G. N. and Christie, P., (2011), 'Mind the gap: Addressing the shortcomings of marine protected areas through large scale marine spatial planning', Marine Policy. Elsevier, 35(2), pp. 226-232. doi: 10.1016/j.marpol.2010.10.006.

Agostini, V. N., Margles, S. W., Knowles, J. K., Schill, S. R., Bovino, R. J. and Blyther, R. J., (2015), 'Ocean \& Coastal Management Marine zoning in St . Kitts and Nevis : A design for sustainable management in the Caribbean', Ocean and Coastal Management. Elsevier Ltd, 104, pp. 1-10. doi: 10.1016/j.ocecoaman.2014.11.003.

Backer, H., (2011), 'Transboundary maritime spatial planning: A Baltic Sea perspective', Journal of Coastal Conservation, 15(2), pp. 279-289. doi: 10.1007/s11852-0110156-1.

Binns, A., (2004), 'Defining a marine cadastre: legal and institutional aspects', Master Thesis, (February), p. 143. Available http://www.csdila.unimelb.edu.au/publication/thesis/Andrew _Binns_Masters_Thesis.pdf.

Binns, A., Collier, P. a and Williamson, I. a N., (2004), 'Developing the Concept of a Marine Cadastre: An Australian Case Study', Integration The Vlsi Journal, No. 6, p. 12.

Blackstock, K. L., Waylen, K. A., Dunglinson, J. and Marshall, K. M., (2015), 'Linking process to outcomes - 
Internal and external criteria for a stakeholder involvement in River Basin Management Planning', Ecological Economics. Elsevier B.V., 77(2012), pp. 113-122. doi: 10.1016/j.ecolecon.2012.02.015.

Burdon, D., Boyes, S. J., Elliott, M., Smyth, K., Atkins, J. P., Barnes, R. A. and Wurzel, R. K., (2015), 'Integrating natural and social sciences to sustainably manage vectors of change in the marine environment: Dogger Bank transnational case study', Estuarine, Coastal and Shelf Science. Elsevier Ltd. doi: 10.1016/j.ecss.2015.09.012.

Buttivant, H. and Knai, C., (2012), 'Improving food provision in child care in England: a stakeholder analysis', Public Health Nutrition, 15(3), pp. 554-60. doi: 10.1017/S1368980011001704.

Calado, H. and Bentz, J., (2013), 'The Portuguese maritime spatial plan’, Marine Policy. Elsevier, 42, pp. 325-333. doi: 10.1016/j.marpol.2013.03.014.

Calado, H., Bentz, J., Ng, K., Zivian, A., Schaefer, N., Pringle, C., Johnson, D. and Phillips, M., (2012), 'NGO involvement in marine spatial planning: A way forward?', Marine Policy. Elsevier, 36(2), pp. 382-388. doi: 10.1016/j.marpol.2011.07.009.

Calado, H., Ng, K., Johnson, D., Sousa, L., Phillips, M. and Alves, F., (2010), 'Marine spatial planning: Lessons learned from the Portuguese debate', Marine Policy, 34(6), pp. 13411349. doi: 10.1016/j.marpol.2010.06.007.

Caldow, C., Monaco, M. E., Pittman, S. J., Kendall, M. S., Goedeke, T. L., Menza, C., Kinlan, B. P. and Costa, B. M., (2015), 'Biogeographic assessments: A framework for information synthesis in marine spatial planning', Marine Policy. Elsevier, 51, pp. 423-432. doi: 10.1016/j.marpol.2014.07.023.

Capistrano, R. C. G., (2007), An institutional analysis of community participation on MPAs within tourism sites in the Philippines. Dalhousie University.

Cárcamo, P. F., Garay-Flühmann, R. and Gaymer, C. F., (2013), 'Opportunities and constraints of the institutional framework for the implementation of ecosystem-based management: The case of the Chilean coast', Ocean \& Coastal Management. Elsevier Ltd, 84, pp. 193-203. doi: 10.1016/j.ocecoaman.2013.08.003.

Carcamo, P. F., Garay-Fluhmann, R., Squeo, F. A. and Gaymer, C. F., (2014), 'Using stakeholders ' perspective of ecosystem services and biodiversity features to plan a marine protected area', Journal of Environmental Management, 40, pp. 116-131. doi: 10.1016/j.envsci.2014.03.003.

Carneiro, G., (2013), 'Evaluation of marine spatial planning’, Marine Policy, 37, pp. 214-229. doi: 10.1016/j.marpol.2012.05.003.

Carter, C., (2014), 'The transformation of Scottish fisheries: Sustainable interdependence from "net to plate"', Marine Policy. Elsevier, 44, pp. 131-138. doi: 10.1016/j.marpol.2013.08.014.

Carvalho, P. and Clarke, B., (1998), 'Ecological sustainability of the South Australian coastal aquaculture management policies', Coastal Management, 26(4), pp. 281-

\section{0. doi: $10.1080 / 08920759809362359$}

Chaffin, B. C. C., Garmestani, A. S. S., Gosnell, H. and Craig, R. K. K., (2016), 'Institutional networks and adaptive water governance in the Klamath River Basin, USA', Environmental Science \& Policy. Elsevier Ltd, 57, pp. 112121. doi: 10.1016/j.envsci.2015.11.008.

Chang, Y. and Lin, B.-H., (2016), 'Improving marine spatial planning by using an incremental amendment strategy: The case of Anping, Taiwan', Marine Policy. Elsevier, 68, pp. 30-38. doi: 10.1016/j.marpol.2016.02.004.

Chen, C. and Tsai, C., (2015), 'Marine environmental awareness among university students in Taiwan: a potential signal for sustainability of the oceans', Environmental Education Research, pp. 1-28. doi: 10.1080/13504622.2015.1054266.

Dunstan, P. K., Bax, N. J., Dambacher, J. M., Hayes, K. R., Hedge, P. T., Smith, D. C. and Smith, A. D. M., (2016), 'Using ecologically or biologically significant marine areas (EBSAs) to implement marine spatial planning', Ocean and Coastal Management. Elsevier Ltd, 121, pp. 116-127. doi: 10.1016/j.ocecoaman.2015.11.021.

Flannery, W. and Cinneide, M. O., (2012), 'A roadmap for marine spatial planning: A critical examination of the European Commission's guiding principles based on their application in the Clyde MSP Pilot Project', Marine Policy, 36, pp. 265-271. doi: 10.1016/j.marpol.2011.06.003.

Frazão, C., Domingos, T., Adelaide, M., Orbach, M. and Andrade, F., (2014), 'How sustainable is sustainable marine spatial planning? Part II - The Portuguese experience', Marine Policy. Elsevier, 49, pp. 48-58. doi: 10.1016/j.marpol.2014.04.005.

Giardino, A., Mulder, J., de Ronde, J. and Stronkhorst, J., (2011), 'Sustainable Development of the Dutch Coast: Present and Future', Journal of Coastal Research, SI(61), pp. 166-172. doi: 10.2112/SI61-001.1.

Gilliland, P. M. and Laffoley, D., (2008), 'Key elements and steps in the process of developing ecosystem-based marine spatial planning', Marine Policy, 32(5), pp. 787-796. doi: 10.1016/j.marpol.2008.03.022.

González, V., Machain, N. and Campagna, C., (2015), 'Legal and institutional tools to mitigate plastic pollution affecting marine species : Argentina as a case study', Marine Pollution Bulletin, 92, pp. 125-133. doi: 10.1016/j.marpolbul.2014.12.047.

Gopnik, M., Fieseler, C., Cantral, L., Mcclellan, K., Pendleton, L. and Crowder, L., (2012), 'Coming to the table: Early stakeholder engagement in marine spatial planning', Marine Policy. Elsevier, 36, pp. 1139-1149. doi: 10.1016/j.marpol.2012.02.012.

Haley, S., Chartier, L., Gray, G., Meek, C., Powell, J., Rosenberg, A. and Rosenberg, J., (2011), Strengthening institutions for stakeholder involvement and ecosystem-based management in the US Arctic offshore. North by, 2020, pp.436-457.

Havard, L., Brigand, L., Cari, M., Cariño, M., Cari, M. and Cariño, M., (2015), 'Ocean \& Coastal Management 
Stakeholder participation in decision-making processes for marine and coastal protected areas: Case studies of the south-western Gulf of', Ocean \& Coastal Management, 116, pp. 116-131. doi: 10.1016/j.ocecoaman.2015.06.017.

Heffernan, P. B., (2015), Enablers Task Force on Marine Spatial Planning. Available at: http://www.ouroceanwealth.ie/publications.

Hernandez, A. L. G., Roof, A. G., Laurent, B., Rosa, M. De, Maries, O. and Durel, Y., (2012), Sustainable port development - The Port of Aalborg case.

Inglés Yuba, E. and Puig Barata, N., (2015), 'Sports management in coastal protected areas. A case study on collaborative network governance towards sustainable development', Ocean \& Coastal Management. doi: 10.1016/j.ocecoaman.2015.07.018.

IOC/UNESCO, IMO, FAO, U., (2011), A Blueprint for Ocean and Coastal Sustainability. Paris.

Jack, E. P. and Raturi, A. S., (2006), 'Lessons learned from methodological triangulation in management research', Management Research News, 29(6), pp. 345-357. doi: 10.1108/01409170610683833.

Jarvis, R. M., Breen, B. B., Krageloh, C. U. and Billington, D. R., (2015), 'Citizen science and the power of public participation in marine spatial planning', Marine Policy. Elsevier, 57, pp. 21-26. doi: 10.1016/j.marpol.2015.03.011.

Jay, S., Ellis, G. and Kidd, S., (2012), 'Marine Spatial Planning: A New Frontier?', Journal of Environmental Policy \& Planning, 14(1), pp. 1-5. doi: 10.1080/1523908X.2012.664327.

Jay, S., Klenke, T., Ahlhorn, F. and Ritchie, H., (2012), 'Early European Experience in Marine Spatial Planning: Planning the German Exclusive Economic Zone', European Planning Studies, 20(12), pp. 2013-2031. doi: 10.1080/09654313.2012.722915.

Jay, S., Klenke, T. and Janßen, H., (2016), 'Consensus and variance in the ecosystem approach to marine spatial planning: German perspectives and multi-actor implications', Land Use Policy. Elsevier Ltd, 54, pp. 129-138. doi: 10.1016/j.landusepol.2016.02.015.

K.K. Baiju, (2013), INSTITUTIONAL ANALYSIS OF MARINE FISHERIES MANAGEMENT PRACTICES IN KERALA, INDIA. Cochin University of Science and Technology.

Karmel, T. S. and Jain, M., (1987), 'Comparison of Purposive and Random Sampling Schemes for Estimating Capital Expenditure', Journal of the American Statistical Association, 82(397), pp. 52-57. doi: 10.1080/01621459.1987.10478390.

Kay, R., Alder, J., Brown, D. and Houghton, P., (2003), 'Management Cybernetics: A New Institutional Framework for Coastal Management', Coastal Management, 31(3), pp. 213-227. doi: 10.1080/08920750390198513.

Kelly, C., Gray, L., Shucksmith, R. and Tweddle, J. F., (2014), 'Review and evaluation of marine spatial planning in the Shetland Islands', Marine Policy. Elsevier, 46, pp. 152-
160. doi: 10.1016/j.marpol.2014.01.017.

Liddle, S. and El-Kafafi, S., (2010), 'World Journal of Entrepreneurship , Management and Sustainable Development', World Journal of Entrepreneurship, Management and Sustainable Development, 6(4), pp. 293305.

Liu, W.-H., Ballinger, R. C., Jaleel, A., Wu, C.-C. and Lin, K.-L., (2012), 'Comparative analysis of institutional and legal basis of marine and coastal management in the East Asian region', Ocean \& Coastal Management. Elsevier Ltd, 62, pp. 43-53. doi: 10.1016/j.ocecoaman.2012.01.005.

Machain, N., Albareda, D., Mianzan, H., Gonza, V. and Campagna, C., (2012), 'Legal and institutional tools to mitigate marine turtle bycatch: Argentina as a case study', Marine Policy, 36, pp. 1265-1274. doi: 10.1016/j.marpol.2012.03.014.

Madu, C. N. and Kuei, C. H., (2012), 'Handbook of Sustainability Management: Sustainable Management’, in, pp. 1-21.

Mangan, J., Lalwani, C. and Gardner, B., (2004), 'Combining quantitative and qualitative methodologies in logistics research', International Journal of Physical Distribution \& Logistics Management, 34(7), pp. 565-578. doi: 10.1108/09600030410552258.

Marine Aquaculture Task Force, (2007), Sustainable Marine Aquaculture: Fulfilling The Promise; Managing The Risks, Marine Aquaculture Task Force.

Nazirah Mohamad Abdullah, Abdullah Hisam Omar, Ghazali Desa and Shuib Rambat, (2014), 'Jurnal Teknologi Space Governance: An Analysis Of Collaborative Design Approach', Jurnal Teknologi (Science \& Engineering), 58, pp. 85-88.

Ng'ang'a, S., Sutherland, M., Cockburn, S. and Nichols, S., (2004), 'Toward a 3D marine cadastre in support of good ocean governance: a review of the technical framework requirements', Computers, Environment and Urban Systems, 28, pp. 443-470. doi: 10.1016/j.compenvurbsys.2003.11.002.

Olsen, E., Fluharty, D., Hoel, A. H., Hostens, K., Maes, F. and Pecceu, E., (2014), 'Integration at the round table: Marine spatial planning in multi-stakeholder settings', PLoS ONE, 9(10), pp. 1-10. doi: 10.1371/journal.pone.0109964.

Ostrom, E., (2005), 'Doing institutional analysis', Handbook of New Institutional Economics, pp. 819-848. doi: 10.1007/978-3-540-69305-5_31.

Ostrom, E., (2010), 'Institutional Analysis and Development: Elements of the framework in historical perspective', Historical developments and theoretical approaches in sociology, II, p. 401.

Ounanian, K., Delaney, A. and Raakjær, J., (2012), 'On unequal footing: Stakeholder perspectives on the marine strategy framework directive as a mechanism of the ecosystem-based approach to marine management', Marine Policy. Elsevier, 36(3), pp. 658-666. doi: 10.1016/j.marpol.2011.10.008.

Perez, M. L., Pido, M. D., Garces, L. R. and Salayo, N. D., (2012), Towards Sustainable Development of Small-Scale Fisheries in the Philippines: Experiences and Lessons 
Learned from Eight Regional Sites. Available at: http://pubs.iclarm.net/resource_centre/WF_3225.pdf.

Pomeroy, R. and Douvere, F., (2008), 'The engagement of stakeholders in the marine spatial planning process', Marine Policy, 32, pp. 816-822. doi: 10.1016/j.marpol.2008.03.017.

Portman, M. E., (2011), 'Marine spatial planning: Achieving and evaluating integration', ICES Journal of Marine Science, 68(10), pp. 2191-2200. doi: 10.1093/icesjms/fsr157.

Portman, M. E., (2015), 'Marine spatial planning in the Middle East: Crossing the policy-planning divide', Marine Policy. Elsevier, 61, pp. 8-15. doi: 10.1016/j.marpol.2015.06.025.

van Putten, I., Cvitanovic, C. and Fulton, E. A., (2016), 'A changing marine sector in Australian coastal communities: An analysis of inter and intra sectoral industry connections and employment', Ocean \& Coastal Management. Elsevier Ltd, 131, pp. 1-12. doi: 10.1016/j.ocecoaman.2016.07.010.

Rajabifard, a., Binns, a. and Williamson, I., (2005), 'Administering the marine environment - the spatial dimension', Journal of Spatial Science, 50(2), pp. 69-78. doi: 10.1080/14498596.2005.9635050.

Richmond, L. and Levine, A., (2012), Institutional analysis of community-based marine resource management initiatives in Hawai 'i and American Samoa.

Roberts, S. J. and Brink, K., (2010), 'Managing Marine Resources Sustainably', Environment: Science and Policy for Sustainable Development, 52(4), pp. 44-52. doi: 10.1080/00139157.2010.493117.

Röckmann, C., Leeuwen, J. Van, Goldsborough, D., Kraan, M. and Piet, G., (2015), 'The interaction triangle as a tool for understanding stakeholder interactions in marine ecosystem based management', Marine Policy. Elsevier, 52, pp. 155162. doi: 10.1016/j.marpol.2014.10.019.

Ryzin, G. G. V. A. N., (2016), 'Cluster Analysis as a Basis for Purposive Sampling of Projects in Case Study Evaluations', pp. 109-119.

Sala, S., Ciuffo, B. and Nijkamp, P., (2015), 'A systemic framework for sustainability assessment', Ecological Economics. The Authors, 119, pp. 314-325. doi: http://dx.doi.org/10.1016/j.ecolecon.2015.09.015.

Sandström, A., Bodin, Ö. and Crona, B., (2015), 'Network Governance from the top - The case of ecosystem-based coastal and marine management', Marine Policy. Elsevier, 55, pp. 57-63. doi: 10.1016/j.marpol.2015.01.009.

Schlüter, A., Wise, S., Mánez, K. S., Morais, G. W. de and Glaser, M., (2013), 'Institutional Change, Sustainability and the Sea', Sustainability, 5(July 2015), pp. 5373-5390. doi: 10.3390/su5125373.

Skurray, J. H., (2015), 'The scope for collective action in a large groundwater basin: An institutional analysis of aquifer governance in Western Australia', Ecological Economics. Elsevier B.V., 114, pp. 128-140. doi: 10.1016/j.ecolecon.2014.12.015.

Soma, K., Tatenhove, J. Van and Leeuwen, J. Van, (2015),
'Ocean \& Coastal Management Marine Governance in a European context: Regionalization, integration and cooperation for ecosystem-based management', Ocean and Coastal Management. Elsevier Ltd. doi: 10.1016/j.ocecoaman.2015.03.010.

Sosa, M. and Zwarteveen, M., (2014), 'The institutional regulation of the sustainability of water resources within mining contexts: accountability and plurality', Current Opinion in Environmental Sustainability. Elsevier B.V., 11, pp. 19-25. doi: 10.1016/j.cosust.2014.09.013.

Sozialwissenschaften, F., (2013), Institutions for sustainable fisheries governance - the case of the commercial Peruvian anchovy fishery der Universität Bremen Milena Arias Schreiber Barba. University of Bremen.

Stelzenm, V., Lee, J., South, A., Foden, J. and Rogers, S. I., (2013), 'Practical tools to support marine spatial planning: A review and some prototype tools', Marine Policy, 38, pp. 214-227. doi: 10.1016/j.marpol.2012.05.038.

Stocker, L. and Kennedy, D., (2009), 'Cultural Models of the Coast in Australia: Toward Sustainability', Coastal Management, 37(5), pp. 387-404. doi: 10.1080/08920750902855998.

Strain, L., Rajabifard, A. and Williamson, I., (2006), 'Marine administration and spatial data infrastructure', 30, pp. 431441. doi: 10.1016/j.marpol.2005.03.005.

Taljaard, S. and Niekerk, L. Van, (2013), 'How supportive are existing national legal regimes for multi-use marine spatial planning? - The South African case', Marine Policy. Elsevier, 38, pp. 72-79. doi: 10.1016/j.marpol.2012.05.021.

Veidemane, K. and Nikodemus, O., (2014), 'Coherence between marine and land use planning: public attitudes to landscapes in the context of siting a wind park along the Latvian coast of the Baltic Sea', Journal of Environmental Planning and Management, 58(6), pp. 949-975. doi: 10.1080/09640568.2014.903167.

Wang, P., Wolf, S. A., Lassoie, J. P. and Dong, S., (2013), 'Compensation policy for displacement caused by dam construction in China: An institutional analysis', Geoforum. Elsevier Ltd, 48, pp. 1-9. doi: 10.1016/j.geoforum.2013.04.009.

Zhang, S., Gao, Y., Feng, Z. and Sun, W., (2014), 'PPP application in infrastructure development in China: Institutional analysis and implications', International Journal of Project Management. Elsevier Ltd and International Project Management Association, 33(0), pp. 497-509. doi: http://dx.doi.org/10.1016/j.ijproman.2014.06.006. 